Monika Małecka

PAN Biblioteka Kórnicka

https://doi.org/10.18778/8220-478-0.17

\title{
WŁOSKIE PASAŻE W BIBLIOTECE KÓRNICKIEJ
}

Streszczenie: Właściciele dóbr kórnickich, Działyńscy i Zamoyscy, jako zagorzali polscy patrioci założyli w XIX wieku wspaniałą kolekcję biblioteczną i muzealną, koncentrując się na zbiorach polskich. Do tego należałoby dołożyć angielski anturaż przebudowanego zamku i ogrodu, w których były one eksponowane oraz szczyptę francuskiego stylu bycia w związku z ich częstymi pobytami wśród paryskiej Polonii. Włoskie klimaty były, ogólnie rzecz biorąc, dalekie od tego, na czy m skupiano uwagę w Kórniku. W zbiorach odnajdujemy jednak kilka świadectw tego, iż kultura włoska była uniwersalna i atrakcyjna bez względu na epokę i zainteresowania. Byly to przejścia między kulturą włoską, zbudowaną na kulturze łacińskiej, a kulturą europejską, a więc i polską. Zrodzily się w wyniku podążania za trendami, nabywania włoskich przedmiotów i podróżowania na Półwysep Apeniński. W artykule przytoczonych zostanie kilka przykładów na poparcie tezy.

Najwcześniejszy motyw włoski dostrzeżemy w XVIIII wieku, kiedy właścicielką Kórnika była Teofila Szołdrska-Potulicka z Działyńskich. Miała ona najprawdopodobniej włoski ogród, który istniał do połowy XIX wieku. Z całą pewnością nie możemy jednak tego stwierdzić, ponieważ źródła sugerują również założenie francuskie.

Pozostałe pasaże związane są z XIX wiekiem. W salonach rozbrzmiewała muzyka włoskich kompozytorów oper. Na półkach bibliotecznych pojawily się liczne stare druki i rękopisy włoskich autorów i wydawców, napisane w języku włoskim. Podróże do Włoch nie były ani częste, ani entuzjastyczne. Głównie stwarzały okazję do politycznej aktywności i spotkań z papieżem, a tylko przy okazji były turystyczną atrakcją. Jan Działyński prowadził na Półwyspie Apenińskim archeologiczne wykopaliska i nabywał przedmioty sztuki starożytnej. Włochy poznajemy oczami rodzin z Kórnika dzięki listom, książkom, kartom pocztowym, obrazom, przedmiotom.

Słowa kluczowe: zbiory Biblioteki Kórnickiej, włoskie rękopisy, włoska muzyka, ogród włoski, podróże do Włoch

Abstract: The Działyńskis and Zamoyskis from Kórnik were mainly associated with the Polish collection, the rebuilt English-style castle and frequent journeys to France. Italian motifs were unnoticeable at first glance which is shown to us by few, preserved 
sources. The universality and the attractiveness of the Italian culture made that it reached Kórnik but these were just transitions between the Italian culture built on the Latin culture and European thus Polish. They were the result of following trends, buying Italian items and travelling to the Apennine Peninsula. The paper presents several examples to support this thesis.

The earliest proof comes from the $18^{\text {th }}$ century when Kórnik was owned by Teofila Szołdrska-Potulicka née Działyńska. She probably had an Italian garden which existed until the middle of the $19^{\text {th }}$ century, but we are not entirely sure because of the historical source materials that also show us the French one. The discussion continues to this day.

Other examples are related to the $19^{\text {th }}$ century. For example, the music of Italian opera composers resounded in salons. The most significant exemplification are numerous old prints and manuscripts of Italian authors and publishers, and in Italian. Travels to Italy were neither frequent nor enthusiastic. They mainly provided an opportunity for political activities and conversations with the Pope. Only by the way they were a tourist attraction. Jan Działyński conducted archaeological excavations there and acquired objects of ancient art. We get to know Italy through their eyes thanks to letters, books, postcards, paintings, objects.

Keywords: collections of the Kórnik Library, Italian manuscripts, Italian music, Italian garden, travels to Italy

Właściciele dóbr kórnickich, Działyńscy i Zamoyscy, jako zagorzali polscy patrioci, założyli w XIX wieku wspaniałą kolekcję biblioteczną i muzealną, koncentrując się na zbiorach polskich ${ }^{1}$. Chodziło o to, aby poprzez zabytki starożytności, którym to mianem wówczas określano eksponaty muzealne i stare księgi, nieustannie budzić polskiego ducha w okresie zaborów, ale i w przyszłości. Do tego należałoby dołożyć angielski anturaż przebudowanego zamku i ogrodu, w których były one eksponowane. Ów styl był po prostu neogotykiem, nazywanym tak, bowiem na Wyspach Brytyjskich w każdym wieku wznoszono budowle zgodnie z tymi kanonami. W zaborze pruskim poprzez osobę architekta i malarza, Karla Schinkla, był on równie eksplorowany, a dla właściciela Kórnika, hr. Tytusa Działyńskiego, stał się równocześnie prostym nawiązaniem do historii tego miejsca, zamku gotyckiego z wieku XV. Do tego obrazu należałoby dodać szczyptę francuskiego stylu bycia, w związku z częstymi pobytami tych rodzin wśród paryskiej Polonii (zwłaszcza uczestników życia politycznego Hotelu Lambert) oraz francuskich księgarzy i drukarzy. Zachowała się bogata korespondencja w języku francuskim oraz przedmioty użytkowe i artystyczne z Francji. Włoskie klimaty były, ogólnie rzec biorąc, dalekie od tego, na czym skupiano uwagę w Kórniku, co pokazują zachowane, stosunkowo nieliczne,

1 Zob. R. Kąsinowska, Zamek w Kórniku, Kórnik 2019. 
świadectwa. Umieszczenie w tytule niniejszych rozważań słowa „pasaże” ma to podkreślać. W dużej mierze są to przejścia między kulturą włoską zbudowaną na kulturze łacińskiej a kulturą europejską, a więc i polską. Włoskość była tak nośna i uniwersalna, że znalazła swoje miejsce również w rodzinie Działyńskich i Zamoyskich z Kórnika. Kilka wybranych przykładów z zakresu architektury krajobrazu, muzykologii, historii książki oraz turystyki pozwoli potwierdzić owo spostrzeżenie. Proweniencje świadectw łączą się z osobami właścicieli i ich bliskich, którzy nabywali przedmioty włoskie, odwiedzali Italię albo naśladowali modę na włoskość 2 .

Chronologicznie pierwszy akcent włoski, choć nieco dyskusyjny, pojawia się w XVIII wieku przy transpozycji otoczenia zamkowego. Jeśli przyjąć za główne źródło dwa wiszące obrazy ${ }^{3}$, powstały wówczas ogród przyzamkowy miał charakter włoski. Na obu dominują pawilony ogrodowe ze schodami, balustradami, arkadami, kolumnami, wazami i rzeźbami w stylu all'antica. $\mathrm{Na}$ jednym z nich znajduje się fontanna, nieodzowny akcent włoskiego krajobrazu, tak miejskiego, jak i wiejskiego ${ }^{4}$. Widoczny jest również niejednorodny charakter otoczenia w postaci skalistego i piaszczystego podłoża oraz otwarcie na pobliskie zabudowania, wzgórza i Półwysep Szyja z gotyckim kościołem parafialnym. Barokowe ogrody włoskie ciągle były jeszcze przedłużeniem renesansowych. Włosi byli bardzo przyzwyczajeni do własnych tradycji. Poza tym ukształtowanie terenu nie sprzyjało rozwinięciu płaskich form ogrodów francuskich. To, co udało się zrobić włoskim ogrodnikom, to rezygnacja z dużej liczby kwater na rzecz bardziej scentralizowanej kompozycji.

Plan z 1801 rokus $^{5}$, choć bardzo ogólny, pokazuje rodzaje terenów zielonych, wchodzących w skład otoczenia zamku. Była to między innymi winnica ${ }^{6}$

2 W niniejszych rozważaniach nie są przedstawiane obiekty zakupione w związku z polityką gromadzenia prowadzoną po II wojnie światowej.

3 BK, sygn. MK 3261: [Panneau dekoracyjne $z$ widokiem Bnina, Kórnika i sztafażem. Pejzaż z widokiem kościoła w Bninie], malarz nieokreślony, 3. ćwierć 18 w.; BK, sygn. MK 3262: [Panneau dekoracyjne $z$ widokiem parku, architektury i sztafażem. Pej$z a \dot{z}$ parkowy $z$ architektura antyczna i sztafażem], malarz nieokreślony, 3. ćwierć. $18 \mathrm{w}$.

4 Ze względu na skwar, ale i chęć zaskoczenia akcentowano ruch wody w postaci: fontanny, wodotrysku, kaskady, wodospadu.

5 BK, sygn. M I 129: Hahn (1801), Plan von dem Lust-Garten, Weinberg und Fasanorie zu Kornik.

6 Niestety plan jest dość enigmatycznie skonstruowany i nie wiemy jak winnica (pole C) była położona w stosunku do zamku. Hodowla krzewów winorośli wspomniana jest również w inwentarzu z $1771 \mathrm{r}$. BK, sygn. BK 780: Protocollon różnych transakcij, przywileiów, ediktów y mandatów w dobrach Maiętności Kórnickiey (1758), k. 187. 
i Zwierzyniec ${ }^{7}$, komponenty włoskich ogrodów. Klimat północnej Europy nie pozwalał na całoroczne przechowywanie drzewek $\mathrm{w}$ alejach, $\mathrm{w}$ donicach $\mathrm{z}$ terra cotty, tak jak w oryginalnych ogrodach Italii. Z zachowanych spisów wiemy, iż właścicielka wzniosła zatem dwie oranżerie, w których uprawiała ciepłolubne rośliny, m.in. drzewka cytryn, pomarańczy, fig, granatów, oleandrów, laurów. Różnorodność gatunkowa hodowanych roślin wzrastała, pojawily się nawet karczochy, aczkolwiek niekoniecznie były to tylko gatunki charakterystyczne dla Półwyspu Apenińskiego.

O włoskości ogrodu kórnickiego poświadcza również wspomnienie z 1835 roku, historyka i współpracownika Tytusa Działyńskiego, Józefa Łukaszewicza: „Ogród napełniony był ptaszarniami i wodotryskami rozmaitego kształtu. Tu sączyła się woda z paszczy lwa [...]; ówdzie tryskały jej strumienie z głowy wieloryba; indziej z paszczy krokodyla. [...] oranżerie zawierały najrzadsze rośliny zagraniczne" ${ }^{\text {. }}$. Choć opis pasuje do włoskiego charakteru, sam autor wspomnień pisze: „[...] tego domu Potulicka w połowie zeszłego wieku, zamek Kurnicki i ogród przy nim w guście francuzkim urządziła".

W czasach Teofili Szołdrskiej-Potulickiej posługiwano się wyłącznie określeniem „ogród włoski”. Choć jest to bardzo trudne do uchwycenia, prawdopodobnie definiowano w ten sposób całość terenu przeznaczonego na zielen' ${ }^{10}$. Pojawiający się jeszcze do połowy XIX wieku w księgach gospodarskich termin

7 Takie miejsce przeznaczone było na dużą zwierzynę, którą obserwowano albo łowiono. W Kórniku Zwierzyniec był za jeziorem już w czasach Stanisława Górki w XVI wieku, a w XVIII Teofila Szołdrska-Potulicka podobno hodowała tam darowanego wielbłąda. W XIX wieku pisano: „W lesie, o półmili od Kurnika jest zwierzyniec, napełniony jeleniami i sarnami”. J. Łukaszewicz (1835), Zamek w Kórniku, „Przyjaciel Ludu”, r. II nr 20, s. 154. Nazwa tego terenu utrzymała się w topografii do dziś. Więcej o tym miejscu R. Kąsinowska, op. cit., s. 327-328; J. W. Kobylański, Zwierzyńce w Kórniku, Poznań 1937.

8 J. Łukaszewicz, op. cit.

Leżące do dziś w przyzamkowym parku angielskim fragmenty osiemnastowiecznej architektury ogrodowej, m.in. basen i posąg lwa z fontanny dowodzą prawdziwości przedstawień. Fotografie zob. R. Kąsinowska, op. cit., s. 284, il. 207 i 208. Fontanny były również w ogrodzie w Runowie Krajeńskim, drugiej posiadłości Teofili Szołdrskiej-Potulickiej. Z roku 1767 zachował się kontrakt na wykonanie prac przez Jana Haltwassera w zakresie kopania rowów do rynien doprowadzających wodę do fontann. BK, sygn. BK 780: Protocollon różnych transakcij, przywileiów, ediktów y mandatów w dobrach Maiętności Kórnickiey (1758), k. 178v.

9 J. Łukaszewicz, op. cit. Późniejsi autorzy z epoki powielają słowa Łukaszewicza.

10 BK, sygn. BK 780: Protocollon różnych transakcij, przywileiów, ediktów y mandatów w dobrach Maiętności Kórnickiey (1758), k. 162v. 
ów jako nazwanie użytkowych ogrodów Działyńskich ${ }^{11}$ zdaje się być nie tylko zachowaniem tradycyjnej nazwy, ale i odniesieniem do włoszczyzny, którą sprowadziła włoska księżniczka, a jednocześnie królowa Polski, Bona Sforza d’Aragona. Niektórzy zdają się doszukiwać genezy użycia terminu w powszechnym nazywaniu ogrodów włoskimi, nawet jeśli takimi nie były ${ }^{12}$.

Nie ulega wątpliwości, iż amatorzy łatwo mogli mylić rozwiązania włoskie z francuskimi, bo często detale decydowały o charakterze kompozycji. Wątpliwości wzbudza również założenie kórnickie. Wykonany na zlecenie Tytusa Działyńskiego plan z ok. 1825 roku pokazuje jednak ogród francuski $^{13}$. Również osiemnastowieczna fascynacja francuszczyzną w Polsce i Europie, bywanie ówczesnej właścicielki zamku, Teofili Szołdrskiej-Potulickiej z Działyńskich w paryskich atelier, remont zamku w stylu francuskim przemawiają za tą drugą koncepcją. Nie ma żadnego potwierdzenia w źródłach o jej zainteresowaniach Italią ${ }^{14}$.

Niektórzy próbują doszukiwać się w ogrodzie kórnickim holenderskiego charakteru, przydawanego przez liczne drzewa owocowe oraz tzw. górkę, czyli widokowy kopiec. Liczne kontakty właścicielki ze sprowadzonymi Olędrami oraz własność pomorskiego majątku, Runowa Krajeńskiego, miały być sposobnością do zachwycenia się właśnie takimi rozwiązaniami ${ }^{15}$. Jakim zatem był osiemnastowieczny ogród kórnicki trudno ostatecznie rozstrzygnąc ${ }^{16}$.

Muzyka salonów dziewiętnastowiecznych rozbrzmiewała rytmami śródziemnomorskimi i nie inaczej było w poznańskim, kórnickim i paryskim salonie

11 M.in. BK, sygn. BK 4424: Regestra przychodu i rozchodu pieniędzy z gospodarstwa pałacowego i ogrodu włoskiego od 1-go lipca 1858 na 1859 rok.

W jednym miejscu pojawia się określenie ogród włoski prawdopodobnie na określenie części rekreacyjnej BK, sygn. BK 6432: Rozchód pieniędzy maj. Kórnickiej od 30go czerwca 1841 do tegoż czasu 1842 r., k. 91v.

12 G. Ciołek, Ogrody polskie, Warszawa 1978, s. 33.

13 BK, sygn. M III 529: Ziehlke (1825), Plan du chatêau du comte Dzialinski auprès de Kurnik et de ses environs.

14 W Kórniku były pewne włoskie tradycje. Podobno poznański biskup i właściciel Kórnika, Uriel Górka sprowadził pod koniec XV wieku ogrodnika z Włoch, Niccolò de Novali, a ogród nazywany był włoskim już w czasach ojca Teofili, Zygmunta Działyńskiego. R. Kąsinowska, op. cit., s. 283.

15 R. Kąsinowska, op. cit., s. 291.

16 Artykuł o zachęcającym tytule: A. Jakuboszczak (2014), Kobieca ręką. Osiemnastowieczne zespoty ogrodowo-parkowe na przykładzie majątku kórnickiego Teofili z Działyńskich Szołdrskiej-Potulickiej, „Studia i Materiały Ośrodka Kultury Leśnej”, nr 13, s. 139-164 również nie rozstrzygnął tej kwestii. Autorka utożsamiła ogród francuski z włoskim. 
Działyńskich i Zamoyskich ${ }^{17}$. Nuty, które się zachowały świadczą o ich użytkowym, a nie kolekcjonerskim charakterze. Nie sposób spotkać bibliofilskich wydań utworów, a kolekcja przypomina naturalne podążanie za modnymi utworami albo tymi, które budzily patriotycznego ducha zwłaszcza w dobie powstań narodowych, w które angażowały się rodziny z Kórnika. Kto był muzycznym wirtuozem w rodzinie - trudno stwierdzić. Wiadomo, że elementem obowiązkowego kształcenia młodziutkich dziewczynek z arystokratycznych rodów była gra na klawikordzie, która miała zapewnić rozrywkę salonowemu towarzystwu. Nieco większe artystyczne aspiracje były udziałem wnuczki Tytusa Działyńskiego, Marii Zamoyskiej. Miała ona dwóch włoskich nauczycieli, którzy działali w Paryżu: Giovanniego Lucantoniego ${ }^{18}$ i Enrica Augusta Delle Sedie ${ }^{19}$. W zbiorach zachował się podręcznik autorstwa Nicola Vaccai ${ }^{20}$, znanego włoskiego nauczyciela śpiewu i kompozytora, z którego pewnie też korzystała Maria Zamoyska. Repertuar lekki, zabawny i taneczny, Francesca Paola Tostiego ${ }^{21}$, kompozytora, który dzięki specjalnym względom u królowej Włoch zyskał ogromną popularność, być może był grywany przez Zamoyską lub przez jej krewne.

Wśród nielicznych zeszytów nutowych ${ }^{22}$ w Bibliotece Kórnickiej odnajdujemy kompozycje Belliniego, Donizettiego, Rossiniego czy Verdiego ${ }^{23}$. Są świadectwem triumfów, jakie święciła opera w XIX wieku. Dziś utwory te kojarzymy zwykle z wielkimi scenami teatralnymi. Wówczas, choć kariery śpiewaków

17 Zamek w Kórniku był rezydencją letnią, stąd mieszkali głównie w Pałacu w Poznaniu przy Starym Rynku. Działalność polityczna, edytorska i kolekcjonerska zmuszała ich także do prowadzenia paryskiego salonu.

18 M. Zamoyska, Wspomnienia, Kórnik 2017, s. 65.

19 Ibidem, s. 66.

20 BK, sygn. N 2252: N. Vaccai (ca 1900), Metodo pratico di canto italiano per camera diviso in quindici lezioni, Milano.

21 BK, sygn. N 2236: F. P. Tosti (ca 1910), T’amo ancora!, Milano.

22 Zaledwie kilkaset z czasów prywatnych właścicieli.

23 BK, sygn. N 261: [Arie i piosenki głównie włoskich kompozytorów m.in.: Belliniego, Donizettiego, Mercadantego, Rossiniego, Stradella] (ca 1910), [s.l.] (brak karty tytułowej stąd tytuł nadany wtórnie; nuty należały do M. Zamoyskiej, wśród nich również utwory lekkie Florimo i Gordigianiego); BK, sygn. N 18: V. Bellini (ca 1840), Norma, Florence; BK, sygn. N 14: G. Donizetti (ca 1840), L'Elisir d'amore, Florence; BK, sygn. N 156: G. Rossini (19 w.), A rispettarmi apprenda Aria di Faraone nel Mosé in Egitto, Milano-Firenze; BK, sygn. N 173: G. Rossini (ca 1830), Cavatina una voce poco fa. Nel Barbiere di Siviglia, [s.l.]; BK, sygn. N 157: G. Rossini (19 w.), Introduzione dell'atto primo nell'opera la Zelmira, Milano; BK, sygn. N 2409: G. Rossini (ca 1850), [Wilhelm Tell. Potpourri na 4 ręce], [s.l.]; BK, sygn. N 152: G. Rossini (ca 1890), 3. Valses. Pour le Piano Forté de l'Opera Otello, Varsovie; BK, sygn. N 2211: G. Verdi (ca 1850), Le Trouvère, Paris; BK, sygn. N 2289: G. Verdi (ca 1850), Les Vêpres siciliennes. Romance, Paris. 
i kompozytorów rodziły się właśnie w takich miejscach, o recepcji twórczości świadczyły nie tylko pełne balkony i rzędy, ale melodie dochodzące $\mathrm{z}$ domowych salonów i wygrywane przez ulicznych kataryniarzy. Za sukcesem opery stała sztuka słowa, muzyki, emocji, komentarzu i dekoracji. Nawet jeżeli brakło tej ostatniej, opera pozostawała wciąż żywa i możliwa do odtworzenia za sprawą ogromnej wartości bel canto.

Najświetniejszym dziełem życia rodziny Działyńskich była biblioteka. Wśród starych ksiąg możemy znaleźć trzy luksusowe egzemplarze manuskryptów powstałych we włoskim kręgu kulturowym ${ }^{24}$, dwie kopie lacińskich dzieł Publiusa Vergiliusa Maro ${ }^{25}$ oraz jedną kopię włoską utworu Dantego ${ }^{26}$. Spośród nich wyróżnia się jeden, typowy dla wczesnego renesansu włoskiego (Il. 1). Z jednej strony zwraca uwagę soczystą zielenią (kontrastującą z indygo stosowanym w księgach francuskich), z drugiej bielusieńkim pergaminem (charta italica - w trakcie garbowania skóry do pobielania powszechnie w Italii stosowano marmur karraryjski) i delikatnymi iluminacjami wstęgowymi o charakterze dekoracyjnym i kaligraficznym. W ten sposób budowano wartość artystyczną kodeksów, nie przysłaniając jednak warstwy tekstowej, która dla humanistów była nieporównanie ważniejsza ${ }^{27}$. Przy lekturze chodziło przede wszystkim o poznanie myśli starożytnych pisarzy świeckich i chrześcijańskich. Badania porównawcze kodeksów nasuwają wniosek, iż w pracowniach iluminatorskich posługiwano się szablonami. Spotykane są również liczne księgi, w których miejsce na inicjał pozostaje puste, aby dzieło było jak najszybciej gotowe, albo aby zmniejszyć koszty wykonania, a tym samym cenę rynkową ${ }^{28}$. Wśród wielobarwnych wstęg dominował kolor biały, tzw. bianchi girari, czyli

24 Zaledwie trzy, bowiem choć włoskie prądy przekraczały granicę Alp, w Polsce więcej ksiąg pochodzi z francuskiego kręgu kulturowego.

25 BK, sygn. BK 625: P. Vergilius Maro (14 w.), Eneida; BK, sygn. BK 626: P. Vergilius Maro (1466), Buccolicorum. Właściwie księga zawiera również Georgiki i Eneidę.

26 BK, sygn. BK 629: D. Alighieri (14-15 w.), La Divina Commedia. W zbiorach jest również wersja inkunabułowa BK, sygn. Inc.F.201: D. Alighieri (1497), La commedia $[\ldots]$, Venezia.

$27 \mathrm{~W}$ kolejnej fazie renesansu owa estetyka zacznie zanikać na rzecz bardziej skomplikowanych form bordiur i miniatur, ale w wymiarze pryncypiów renesansowych ( $w$ ornamentyce powrót do antyku i starochrześcijańskich pisarzy kościelnych X, XI I XII wieku, wskazanie na człowieka m.in. poprzez podkreślenie ruchu w postaciach i wprowadzenie otoczenia, głównie architektury, profuzja detali, zwłaszcza florystycznych, liczne kontrapunkty).

28 Często pozostawiano także miejsce puste na karcie tytułowej, aby właściciel mógł umieścić tam swój herb jako formę ekslibrisu. Niektórzy badacze mówią o ówczesnym upadku iluminatorstwa i postrzeganiu go jako jednej z dziedzin rzemiosła. 
białych winorośli, uzyskiwany poprzez pozostawienie białych pól pergaminu. Motyw ten nieodłącznie związany był z florenckimi, umbryjskimi, ferraryjskimi i neapolitańskimi renesansowymi pracowniami dzięki księgarzowi, Vespasianowi da Bisticci, który jako pierwszy miał go użyć do ozdabiania ksiąg w tym czasie.

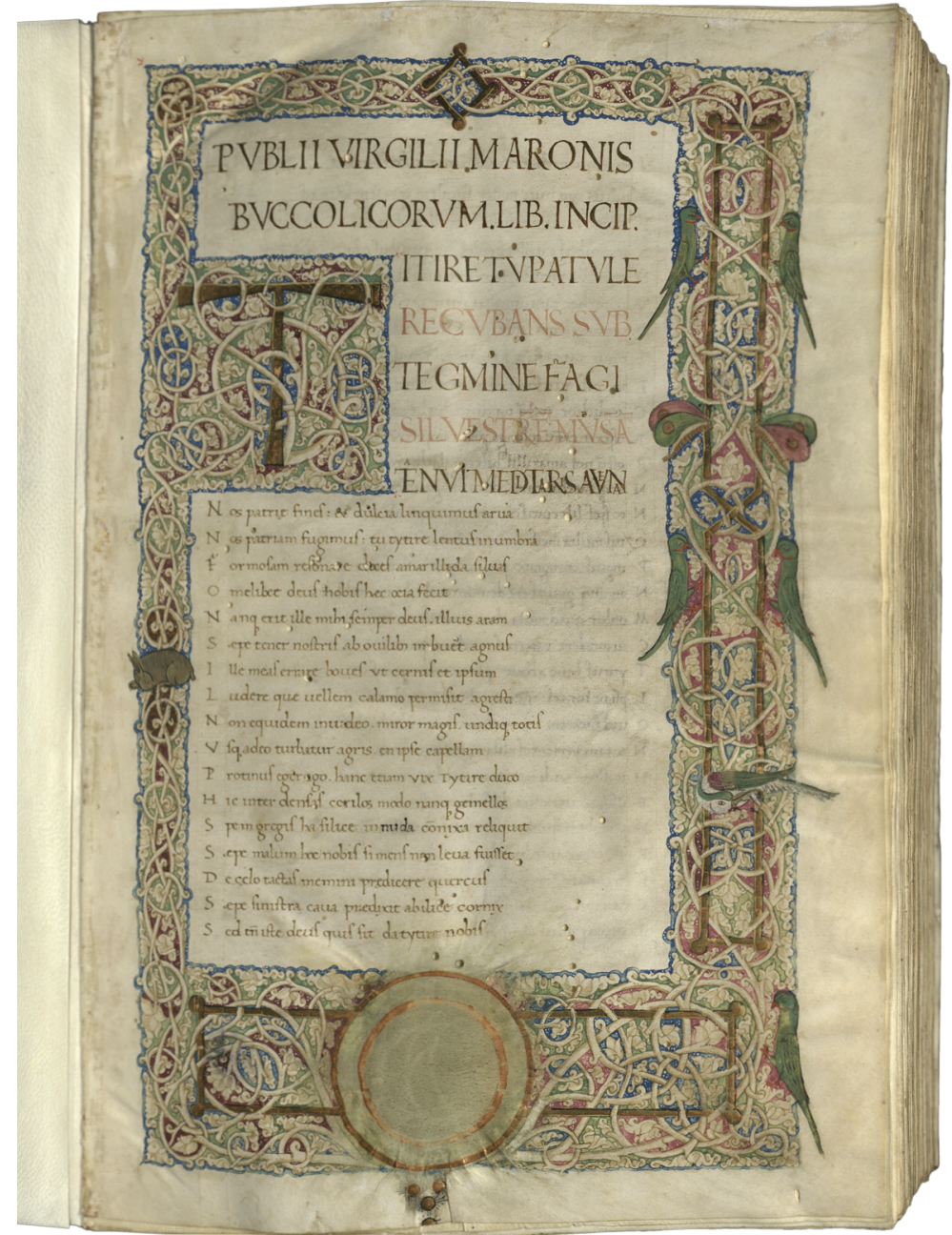

Il. 1. BK, BK 626, k. 1: P. Vergilius Maro, Buccolicorum, 1466, skan PAN Biblioteka Kórnicka

Zob. I. Berkovits, Corviniana. Iluminowane rękopisy biblioteki Króla Macieja Korwina, Wrocław-Budapest 1964, s. 12. 
Niestety nie mamy pewności co do pochodzenia rękopisu kórnickiego. Żadne pozostawione spisy, rachunki czy notatki nie przybliżają nas do odpowiedzi na pytanie, który z Działyńskich nabył to dzieło ${ }^{29}$. Jedynie intuicja i inne przykłady podpowiadają, iż tej rangi dzieła kupował Tytus Działyński, ponieważ pasji bibliofilskiej poświęcał najwięcej czasu. Trudno jednak powiedzieć, jak to się miało do poloników, które stanowiły właściwy przedmiot zainteresowania Działyńskich. Być może kluczem do rozwiązania tej zagadki jest postać Filippa Buonaccorsiego zwanego Kallimachem, najsłynniejszego Włocha w Polsce doby renesansu. Jego postać badacze wiążą z Marsiliem Ficinem, a tego z kolei z Pietro Cenninim ${ }^{30}$, którego prace zdobnicze są najbardziej zbliżone do egzemplarza kórnickiego ${ }^{31}$. Niestety, są to tylko hipotezy.

29 Dotychczasowa kwerenda nie przyniosła rezultatów w tym zakresie. Wiemy również od Jana Działyńskiego o licznych brakach w dokumentacji: „[...] z jednej strony do nieładu bardzo licznych dokumentów, wśród których szukać wypada biblioteki nieuporządkowanej przyczyniłem się dokupując przeszło 30.000 już dołączonych. $\mathrm{Z}$ drugiej odkupiłem 15 przeszło centnarów wykradzionych z biblioteki, z których brakująca część posłużyła za zawijanie śledzi medale i monety. Następnie Matka moja oddawała mi papiery Ojca tylko w miarę jak je przeglądała i tylko takie lub te które już była przejrzała i które oddać chciała powróciwszy do kraju po śmierci Ojca, nigdy nigdzie nie zastałem i nie objąłem razem papierów po moim Ojcu. Czego jawnym dowodem strata nieoceniona i nieodżałowana autografu Ojca do życia Jana Zamoyskiego spalonego zdaje się przez jakiś fanatyków, którzy z powodów religijnych przywłaszczyli sobie kilka kopii najobszerniejszej pracy historycznej mego Ojca. Wreszcie policya poznańska zabrała bez spisu i względu na treść z domu naszego w Poznaniu kilka kufrów papierów w znacznej części mego Ojca, sądząc, że są moje. Właśnie zwróciła jeden [...]” BK, sygn. BK 7444: Listy do Jana Dziatyńskiego w sprawach bibliotecznych i wydawniczych (1852-1880), s. 269-269v, Brudnopis Jana Działyńskiego jako odpowiedź na korespondencję J. Morawskiego.

Odnajdujemy jedynie wzmianki o pochodzeniu druków wergiliańskich: BK, sygn. BK 7462: Nabytki Biblioteki Kórnickiej w l. 1844-1872 m.in. rejestr Kielisińskiego 1844-1847 spis Lelewelianów ręka Lelewela etc., k. 46; BK, sygn. BK 7460: K. W. Kielisiński (1840-1843), Księga wydatków i czynności Biblioteki Kórnickiej, k. 152; BK, sygn. BK 593: T. Działyński (1825), Katalog druków Biblioteki Kórnickiej (A-R), przeważnie polonica, k. 15v-16, 40v-41; E. Bątkiewicz-Szymanowska, M. Marcinkowska (2018), Księgozbiór Ksawerego Dziatyńskiego. Charakterystyka inwentarza, „Pamiętnik Biblioteki Kórnickiej”, nr 35, s. 148, 152, 196.

Ponadto na półkach znajduje się blisko 41 egzemplarzy dzieł Vergiliusa wydanych do 1900 roku. Wszystkie trafiły tam jeszcze w XIX wieku.

30 J. Zathey, Katalog rękopisów średniowiecznych Biblioteki Kórnickiej, Wrocław i in. 1963, s. 421.

31 I. Berkovits, op. cit., s. 32-36; K. Dobrowolski, Rękopis Bibljoteki Macieja Korwina przechowywany w Muzeum XX. Czartoryskich w Krakowie, Kraków 1926. 
Trzymając się faktów, mamy jedynie nazwisko pisarza z okolic Sieny i Volterry, Philippusa Giotti Radicundolensis, który posłużył się łaciną i pismem humanistycznym. Choć na karcie tytułowej, w dolnej części bordiury, wplecione było miejsce na herb, trudno rozstrzygnąć, czy miejsce to było puste czy wypełnione, a później skrupulatnie wydrapano pigmenty, aby namalować nowy ${ }^{32}$. Być może dokładne badania fizyczne przy użyciu specjalistycznej aparatury pozwoliłyby rozstrzygnąć wątpliwość. Wspomniane nazwiska, treść dzieła ${ }^{33}$, ale również oryginalnie zachowana dolna okładzina ${ }^{34}$ wskazują jeszcze na jedną, najbardziej prawdopodobną wersję. Otóż dzieło mogło zostać wykonane na zamówienie króla Węgier, Macieja Korwina. Biblioteka węgierskiego władcy słynęła z dzieł renesansowych, zarówno kupowanych na rynku włoskim, jak i tworzonych na wzór owych we własnych pracowniach ${ }^{35}$. Przetransportować dzieło mogli do Krakowa w XVI wieku studenci węgierscy ${ }^{36}$. Rękopis mógł dostać się w ręce Działyńskiego także w zupełnie nieoczywisty sposób w związku z wcześniejszymi grabieżami kolekcji ${ }^{37}$.

W magazynach kórnickich stoją na półkach liczne jeszcze dzieła pisarzy włoskich ${ }^{38}$, napisane w języku włoskim lub wydane we Włoszech. Obecnie zidentyfikowano ponad 400 tekstów włoskich w samych rękopisach i starych drukach (ze znaczącą przewagą tych drugich). Trudno policzyć włosko brzmiące nazwiska. $\mathrm{Z}$ pewnością nie są to pełne dane ze względu na ubogie

32 J. Zathey twierdzi, że było wypełnione; zob. Zathey, op. cit., s. 420.

33 Najliczniejsze wśród corvinianów były dzieła starożytnych klasyków (57 tytułów), a później pisarzy starochrześcijańskich (43 tytuły). I. Berkovits, op. cit., s. 18; C. Csapodi, Historia biblioteki króla Macieja Korwina, [w:] Bibliotheca Corviniana. $Z$ dziejów kultury węgierskiej w późnym średniowieczu, P. Tafiłowski (red.), Warszawa 2006, s. 54-55.

34 Bordiura wypełniona orientalną plecionką charakterystyczną dla włoskich opraw renesansu i złote puncowanie. Zob. przykład A. Semkowicz, Introligatorstwo $z$ krótkim zarysem historii zdobnictwa opraw i 89 rycinami $w$ tekście, Kraków 1948, s. 169-170. Także C. Csapodi, op. cit., s. 35; Á. Miko, Dalsze dzieje biblioteki Macieja Korwina, [w: ] op. cit., P. Tafiłowski (red.), s. 167.

35 W Budzie działał warsztat iluminowania, kopiowania i oprawiania ksiąg. Więcej zob. I. Berkovits, op. cit., s. 16, 78-100.

36 Zob. K. Dobrowolski, op. cit., s. 15-16; E. Kovács, Uniwersytet krakowski a kultura węgierska. Przyczynki do historii węgiersko-polskich stosunków kulturalnych wieków XV i XVI, Budapest 1965; P. Tafiłowski, Wstęp, [w:] P. Tafiłowski (red.), op. cit., s. $12-13$.

37 Zob. C. Csapodi, op. cit., s. 67-72.

38 Wśród nazwisk warto wymienić: Francesca Petrarkę, Giovanniego Boccaccia, Niccolò Machiavellego, Ludovica Ariosta, Torquata Tassa, Carla Goldoniego. 
opisy jeszcze wielu rękopisów i starych druków z blisko 55000 przechowywanych w Bibliotece Kórnickiej ${ }^{39}$.

Analiza życiorysów osób związanych z Kórnikiem pokazuje, że właściwie tylko o jednej z nich można powiedzieć, iż kochała podróżować. Pozostałe wyprawy odbywały się jakby mimochodem, bez specjalnego entuzjazmu. Częste wyjazdy Działyńskich i Zamoyskich do Paryża były raczej koniecznością polityczną aniżeli przyjemną rozrywką. Włoskie wojaże były epizodyczne ${ }^{40}$ i nie były spełnieniem marzeń nikogo z rodziny. Italię ich oczami poznajemy dzięki listom, książkom o zabytkach, pocztówkom, obrazom, przedmiotom.

Najbardziej imponujące były podróże i kontakty z lat 1865-1868 przedostatniego właściciela Kórnika, hr. Jana Działyńskiego, ponieważ wiązały się z nabyciem wartościowych obiektów archeologicznych, głównie waz attyckich z Noli i Kapui ${ }^{41}$. W ten sposób Działyński stworzył jedną z cenniejszych kolekcji antycznych na świecie. Trudno do końca wyjaśnić jego przelotną fascynację $e^{42}$, ale z pewnością wpisywała się ona w zainteresowania kolekcjonerskie elit Europy. Począwszy od XVIII wieku, chętnie zatrudniano archeologów, naukowców, antykwariuszy, pośredników, miejscowych plenipotentów,

39 Żadnych danych nie jesteśmy w stanie przedstawić w stosunku do pozostałych zbiorów bibliotecznych: druków od 1800 roku, zbiorów szachowych, czasopism, dokumentów życia społecznego oraz zbiorów muzealnych.

40 Np. źródła wskazują, że małżonka Tytusa Działyńskiego, Gryzelda Celestyna Działyńska z Zamoyskich była trzykrotnie we Włoszech (przed 1837 w Loreggio, w 1937 we Florencji, w 1870 w Rzymie); Władysław Zamoyski był na wakacjach z ojcem, gen. Władysławem Zamoyskim w Rzymie w roku 1862.

41 Okolice Neapolu uważano za bramę do świata śródziemnomorskiego.

42 Działyński już wcześniej zbierał zabytki archeologiczne z terenu ojczyzny (J. Fogel (1970), Z dziejów archeologii wielkopolskiej XIX wieku: działalnoś́ Tytusa i Jana Działyńskich, „Fontes Archeologici Posnanienses”, wol. XX (1969), s. 247-267). Wiemy, iż jego pasję podzielała małżonka. Właściwie podróżowali w trójkę, bo często towarzyszył im również Władysław Czartoryski, szwagier Działyńskiego. Dominuje pogląd, iż to Działyński inspirował pozostałych do nabywania śródziemnomorskich precjozów, a przy tym był wytrawnym mecenasem sztuki, stąd jego nazwisko w rubryce twórca kolekcji. Jednoznacznie nie udało się wskazać liczby nabytych obiektów, ale zazwyczaj mówi się o około 100. Więcej zob. A. Mężyński, Jan Dziatyński 1829-1880, Wrocław i in. 1987, s. 149-155; D. Gorzelany, Europejska moda kolekcjonerska a idea polskiego „zaktadu naukowego”. Zbiór sztuki starożytnej księcia Wtadystawa Czartoryskiego, [w:] K. Kłudkiewicz, M. Mencfel (red.), Miłośnictwo rzeczy. Studia z historii kolekcjonerstwa na ziemiach polskich w XIX wieku, Warszawa 2014, s. 240-261; K. Kłudkiewicz, Wybór i konieczność. Kolekcje polskiej arystokracji w Wielkopolsce na przetomie XIX i XX wieku, Poznań 2017, s. 38-42, 72; I. Głuszek, Jan i Izabela Działyńscy - kolekcjonerzy sztuki antycznej, [w:] Życie sztuką. Gołuchów Izabeli z Czartoryskich Działyńskiej, Poznań 2018, s. 62-71. 
aby zdobyć oryginalne artefakty kultury antycznej Italii. Podobnie czynił Dziatyński, stąd w zbiorach zachowały się listy, rachunki, notatki i rysunki potwierdzające koneserskie poczynania hrabiego ${ }^{43}$. Same przedmioty nigdy nie trafily do Kórnika. Początkowo gromadzono je w Paryżu, a w latach 70. przewieziono je do zamku w Gołuchowie, w Wielkopolsce, gdzie częściowo są do teraz. Znalazły się tam jako spłata długu zaciągniętego przez męża u swojej małżonki, księżniczki Izabelli Działyńskiej z Czartoryskich ${ }^{44}$. Nie wiadomo dlaczego w Kórniku możemy podziwiać dwa przedmioty z tych zakupów: mozaikę cave canem i majolikę istoriato ${ }^{45}$. Czarno-biała mozaika (Il. 2) jest całością, ponieważ ma formę zamkniętego pierścienia, w którym znajduje się wizerunek psa. Tego typu dekoracje Rzymianie umieszczali we frontowych pomieszczeniach, aby uczulić gości na obecność zwierzęcia w domu ${ }^{46}$. Majolika to tradycyjny wyrób ceramiczny, w jaskrawych barwach. Egzemplarz kórnicki ma formę talerza dekoracyjnego z głównym wątkiem nawiązującym do twórczości Botticellego i Raffaella. Zresztą prace tych artystów były najczęstszą inspiracją dla garncarzy. Omawiane naczynie ukazuje nagą Venere bella madre da amore w postawie subtelnego ruchu na delikatnej muszli, a w jej otoczeniu liczne bóstwa wodne w pozach $\mathrm{z}$ alkowy ${ }^{47}$.

43 BK, sygn. BK 7471: Materiaty dot. zakupu wykopalisk wtoskich przez Jana Dzialyńskiego (1867-1868); BK, sygn. BK 7327/2: Rachunki Jana Dzialyńskiego (1849-1880), k. 23-24, 34-42, 44.

44 Więcej zob. m.in. T. Jakimowicz (1982), Od kolekcji „Curiosités artistiques” ku muzeum. Zbieractwo artystyczne Izabelli $z$ Czartoryskich Dziatyńskiej w latach 1852-1899, „Studia Muzealne”, z. 13, s. 24-28.

45 BK, sygn. MK 2922: Mozaika cave canem, Pompeje I w. n. e.; BK, sygn. BK 7471: Materiały dot.zakupu wykopalisk włoskich przez Jana Działyńskiego (1867-1868), s. 97; BK, sygn. MK 3810: F. Durantino (ca 1543-1545), Majolika istoriato, Urbino.

W zbiorach jest jeszcze waza (BK, sygn. MK 4055), o której niewiele wiadomo. Być może jest to falsyfikat zakupiony przez Działyńskiego. Niestety dotychczas nie prowadzono badań nad tym obiektem. O tyle byłaby to zadziwiająca historia, iż Działyński wystrzegał się falsyfikatów, których było mnóstwo na rynku. Zob. BK, sygn. BK 7471: Materialy dot. zakupu wykopalisk wtoskich przez Jana Dziatyńskiego (1867-1868), k. 81.

46 Niestety obiekt nie jest opisany w literaturze przedmiotu, ale o tego typu dekoracjach więcej zob. I. Ferris, Cave canem. Animals and roman society, Stroud 2018, s. $45-46$.

47 Więcej zob. Ceramika Rafaela. Majolika istoriato ze zbiorów polskich, E. K. Świetlicka (red.), Warszawa 2010, s. 98-99. 


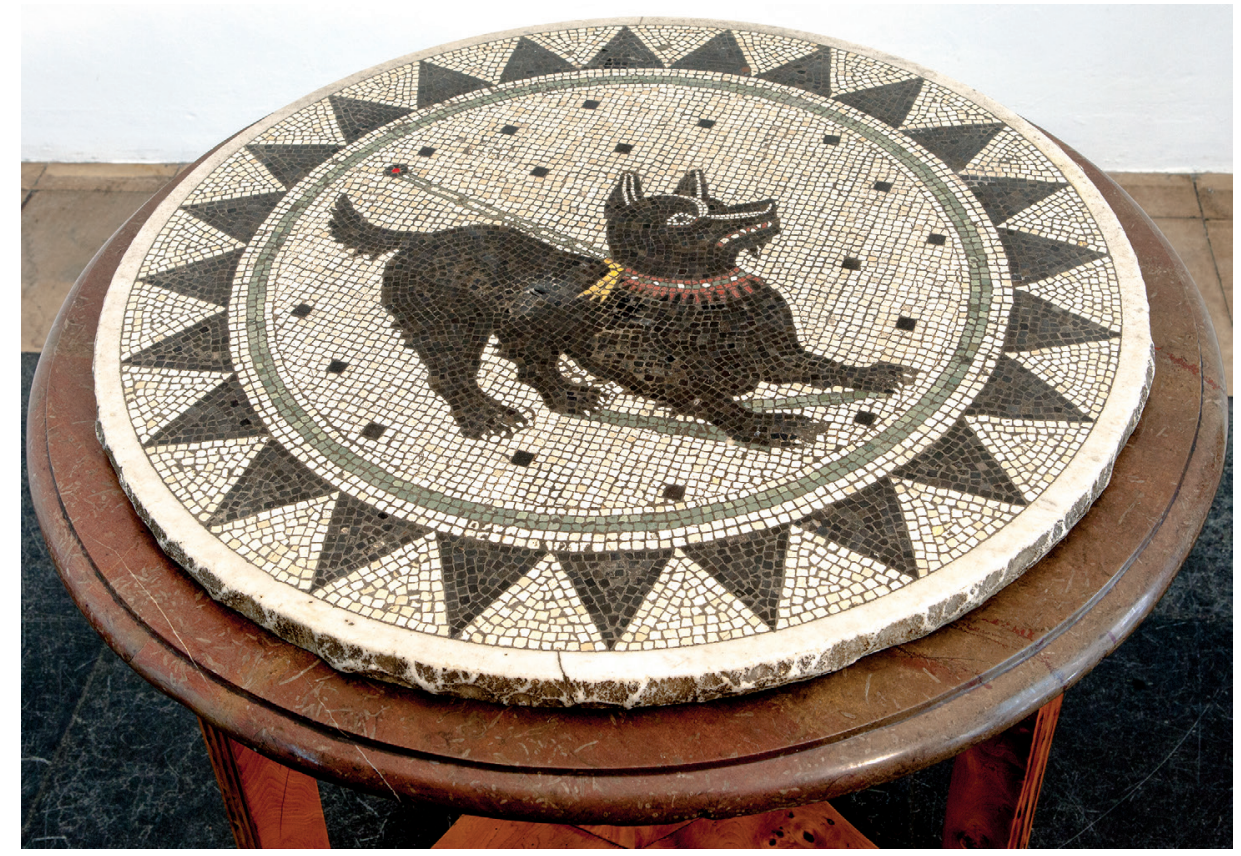

Il. 2. BK, MK 2922: Mozaika cave canem, Pompeje I w. n. e., fot. Zdzisław Nowakowski PAN Biblioteka Kórnicka

Najczęściej wracał do Włoch gen. Władysław Zamoyski, który nauczył się nawet języka. Pierwsza jego podróż w wieku 26 lat wiązała się ze spotkaniem z bratem w Neapolu. Udało mu się zwiedzić również Sycylię, Pompeje, Herkulanum, Charybdę, Scyllę, Rzym, Perugię, Sienę, Florencję, Bolonię, Padwę, Wenecję, Triest ${ }^{48}$. Florencję odwiedzał wielokrotnie, najpierw towarzysząc matce, Zofii Zamoyskiej z Czartoryskich, w jej chorobie, a później nawiedzając jej grób w kościele Santa Croce. Włochy dla Zamoyskiego były również areną działań niepodległościowych. Brał udział w wojnie austriacko-piemonckiej. Obracal się w środowisku polityków, dyplomatów, duchownych oraz papieży, Grzegorza XVI i Piusa IX. To tam poznal Adama Mickiewicza i Zygmunta Krasińskiego. Żywo interesowal się upadkiem Państwa Kościelnego i powstaniem zjednoczonych Włoch. W rzymskich wojażach roku 1862 i 1867 towarzyszyli mu najbliżsi. Istotna jest druga data, bowiem wówczas wraz z małżonką, Jadwigą Zamoyską z Działyńskich, uczestniczył w kanonizacji Jozafata

48 Podobną podróż alla Grand Tour odbyl jego ojciec, Stanisław Kostka Zamoyski z rodziną, w okresie od końca 1790 do jesieni 1791. Zob. K. Ajewski, Stanistawa Kostki Zamoyskiego życie i działalność 1775-1856, Warszawa 2010, s. 42-45. 
Kuncewicza $^{49}$. Drugie spotkanie Jadwigi Zamoyskiej z głową Kościoła miało miejsce na prywatnej audiencji u kolejnego papieża, Leona XIII. Wraz z córką, Marią Zamoyską, starały się one wtedy o aprobatę dla założonej w duchu katolickim szkoły dla dziewcząt (Szkoły Domowej Pracy Kobiet) ${ }^{50}$. Nie była to ostatnia wizyta $\mathrm{w}$ komnatach watykańskich, bowiem Zamoyskie prosily o błogosławieństwo kolejnego papieża, Piusa $\mathrm{X}^{51}$. Przy okazji zwiedzały Wieczne Miasto. Zachowały się barwne opisy miejsc i osób autorstwa Jadwigi Zamoyskiej, która znana była z intrygujących opowieści o pasji podróżniczej ${ }^{52}$.

Przytoczone przykłady obrazują przejawy włoskości u Działyńskich i Zamoyskich z Kórnika, nie wyczerpują jednak zagadnienia. Nie został tutaj podjęty chociażby wątek włoskich artystów, których twórczość w czasach stanisławowskich, ale i późniejszych, współtworzyła polską kulturę oraz dziedzictwo rodów kórnickich. Okres chronologiczny jest dość mocno zawężony, co wynika z braku źródeł, skąpej literatury, a przede wszystkim braku przejawów włoskości mniej więcej do połowy XVIII wieku. Z przeglądu jednoznacznie wynika, iż pojęta bardzo szeroko kultura włoska była immanentnie związana z kulturą polską i europejską. Przyczyn tego stanu było wiele: powszechne mody, chwytliwość nowych koncepcji, indywidualne zainteresowania, ośrodek katolicyzmu i najważniejsze - uniwersalność wartości przejętych jako dziedzictwo antyku. Badania proweniencyjne w wielu wypadkach nie przynoszą efektów i dziś możemy snuć jedynie hipotezy o wplywach włoskich w Kórniku. Nie można udzielić

49 Więcej zob. zwłaszcza W. Zamoyski, Jenerał Zamoyski 1803-1868, 1803-1830 t. 1, Poznań 1910, s. 301-326; W. Zamoyski, Jenerał Zamoyski 1803-1868, 1832-1837 t. 3, Poznań 1914, s. 390-392, 396-417, 431-442; W. Zamoyski, Jenerat Zamoyski 1803-1868, 1837-1847 t. 4, Poznań (1918), s. 229-235, 392-410, 476, 481-488; W. Zamoyski, Jenerat Zamoyski 1803-1868, 1847-1852 t. 5, Poznań 1922, s. 38-71, 74-98, 136-223; W. Zamoyski, Jenerat Zamoyski 1803-1868, 1853-1868 t. 6, Poznań 1930, s. 287-301, 307-319, 397-400, 397-401, 408-410, 489-490, 492-497, 499-500; J. Nowak, Władysław Zamoyski. O sprawe polska w Europie (1848-1868), Poznań 2002; K. Czachowska, Generałowa Jadwiga Zamoyska (1831-1923). Życie i dzieło, Poznań 2011, s. 224-226.

50 Więcej zob. zwłaszcza K. Czachowska, op. cit., s. 266-267; M. Zamoyska, op. cit., s. 134-139.

51 M. Zamoyska, op. cit., s. 204-211; BK, sygn. BK 7551: Różne życiorysowe Jadwigi Zamoyskiej notatki, wyciagi, wspomnienia o J. Zamoyskiej zapiski dot. Zakładu w Kuźnicach etc. (19-20 w.), s. 373-374, 376; BK, sygn. BK 7598/2: M. Zamoyska (1896-1906), Listy Marii Zamoyskiej do matki Jadwigi Zamoyskiej, t. 2, s. 985-992, 994-1007.

52 BK, sygn. BK 7612: J. Zamoyska (1856-1921), Listy Jadwigi Zamoyskiej do różnych, s. 95-103; BK, sygn. BK 7342: J. Zamoyska (1852-1882), Listy Jadwigi z Działyńskich Zamoyskiej do siostry Cecylii Działyńskiej, s. 115-178. 
odpowiedzi na pytania kto, gdzie, kiedy, za ile, od kogo, w jakim celu. Podróże były z pewnością doskonałą okazją do wypoczynku, zobaczenia i zainspirowania się pięknymi miejscami oraz przywiezienia souvenirów. Dla rodziny Działyńskich i Zamoyskich stanowiły także okazję do spotkania głowy Kościoła, ale i głowy Państwa, Ojca Świętego. Poza tym, pod względem politycznym było to raczej jedno z wielu miejsc, które można było wykorzystać do aspiracji niepodległościowych własnej ojczyzny. Dla Jana Działyńskiego było centrum realizacji jego krótkotrwałej i tajemniczej fascynacji archeologicznymi wykopaliskami. Podążanie za włoskimi melodiami i ogrodami miało charakter zbiorowej fascynacji. Pośród włoskich pasaży najbardziej niezwykła jest kolekcja ksiąg, której z pewnością nie można nazwać zbiorem poloników, a więc co do zasady nie powinna współtworzyć skarbca Biblioteki Kórnickiej. Tworzy ona jednak europejskie dziedzictwo kulturowe, które pobudzało umysły i emocje również polskich artystów przez wieki.

Działyńscy i Zamoyscy doświadczali włoskości głównie w pozostawionym dziedzictwie materialnym. Mniej uważni byli na atmosferę, przyrodę, ludzi. Być może owa różnica wynika z trudności w opisywaniu zjawisk niematerialnych, a być może dlatego, iż nie czuli lub nie rozumieli oni ducha tych ziem na tyle mocno.

\section{Bibliografia}

\section{Źródla}

PAN Biblioteka Kórnicka, sygn. BK 593, BK 625, BK 626, BK 629, BK 780, BK 4424, BK 6432, BK 7327/2, BK 7342, BK 7444, BK 7460, BK 7462, BK 7471, BK 7551, BK 7598/2, BK 7612, Inc.F.201, M I 129, M III 529, MK 2922, MK 3261, MK 3262, MK 3810, MK 4055, N 14, N 18, N 152, N 156, N 157, N 173, N 261, N 2211, N 2236, N 2252, N 2289, N 2409

\section{Opracowania}

Ajewski K., Stanistawa Kostki Zamoyskiego życie i działalność 1775-1856, Warszawa 2010.

Bątkiewicz-Szymanowska E., Marcinkowska M., Księgozbiór Ksawerego Dziatyńskiego. Charakterystyka inwentarza, „Pamiętnik Biblioteki Kórnickiej” 2018, nr 35, s. 131-200.

Berkovits I., Corviniana. Iluminowane rękopisy biblioteki Króla Macieja Korwina, Wrocław-Budapest 1964.

Ceramika Rafaela. Majolika istoriato ze zbiorów polskich, E. K. Świetlicka (red.), Warszawa 2010. Ciołek G., Ogrody polskie, Warszawa 1978.

Csapodi C., Historia biblioteki króla Macieja Korwina, [w:] P. Tafiłowski (red.), Bibliotheca Corviniana. Z dziejów kultury wegierskiej w późnym średniowieczu, Warszawa 2006, s. 34-73.

Czachowska K., Generałowa Jadwiga Zamoyska (1831-1923). Życie i dzieto, Poznań 2011.

Dobrowolski K., Rękopis Bibljoteki Macieja Korwina przechowywany w Muzeum XX. Czartoryskich w Krakowie, Kraków 1926. 
Ferris I., Cave canem. Animals and roman society, Stroud 2018.

Fogel J., Z dziejów archeologii wielkopolskiej XIX wieku: dziatalność Tytusa i Jana Działyńskich, „Fontes Archeologici Posnanienses” 1970, vol. XX (1969), s. 247-267.

Głuszek I., Jan i Izabela Działyńscy - kolekcjonerzy sztuki antycznej, [w:] Życie sztuką. Gołuchów Izabeli z Czartoryskich Działyńskiej, Poznań 2018, s. 62-71.

Gorzelany D., Europejska moda kolekcjonerska a idea polskiego „zakładu naukowego”. Zbiór sztuki starożytnej księcia Władysława Czartoryskiego, [w: ] K. Kłudkiewicz, M. Mencfel (red.), Miłośnictwo rzeczy. Studia $z$ historii kolekcjonerstwa na ziemiach polskich w XIX wieku, Warszawa 2014, s. 240-261.

Jakimowicz T., Od kolekcji „Curiosités artistiques” ku muzeum. Zbieractwo artystyczne Izabelli z Czartoryskich Działyńskiej w latach 1852-1899, „Studia Muzealne” 1982, z. 13, s. 24-28.

Jakuboszczak A., Kobieca ręka. Osiemnastowieczne zespoty ogrodowo-parkowe na przykładzie majątku kórnickiego Teofili z Działyńskich Szołdrskiej-Potulickiej, „Studia i Materiały Ośrodka Kultury Leśnej” 2014, nr 13, s. 139-164.

Kąsinowska R., Zamek w Kórniku, Kórnik 2019.

Kłudkiewicz K., Wybór i konieczność. Kolekcje polskiej arystokracji w Wielkopolsce na przełomie XIX i XX wieku, Poznań 2017.

Kobylański J. W., Zwierzyńce w Kórniku, Poznań 1937.

Kovács E., Uniwersytet krakowski a kultura węgierska. Przyczynki do historii wegiersko-polskich stosunków kulturalnych wieków XV i XVI, Budapest 1965.

Łukaszewicz J., Zamek w Kórniku, „Przyjaciel Ludu” 1835, r. II nr 20, s. 153-155.

Mężyński A., Jan Działyński 1829-1880, Wrocław i in. 1987.

Miko Á. Dalsze dzieje biblioteki Macieja Korwina, [w:] P. Tafiłowski (red.), Bibliotheca Corviniana. Z dziejów kultury węgierskiej w późnym średniowieczu, Warszawa 2006, s. 146-180.

Nowak J., Wtadystaw Zamoyski. O sprawę polska w Europie (1848-1868), Poznań 2002.

Semkowicz A., Introligatorstwo z krótkim zarysem historii zdobnictwa opraw i 89 rycinami $w$ tekście, Kraków 1948.

Tafiłowski P., Wstęp, [w:] P. Tafiłowski (red.), Bibliotheca Corviniana. Z dziejów kultury węgierskiej w późnym średniowieczu, Warszawa 2006, s. 5-29.

Zamoyska M., Wspomnienia, Kórnik 2017.

Zamoyski W., Jenerat Zamoyski 1803-1868, 1803-1830 t. 1, Poznań 1910.

Zamoyski W., Jenerat Zamoyski 1803-1868, 1832-1837 t. 3, Poznań 1914.

Zamoyski W., Jenerat Zamoyski 1803-1868, 1837-1847 t. 4, Poznań 1918.

Zamoyski W., Jenerat Zamoyski 1803-1868, 1847-1852 t. 5, Poznań 1922.

Zamoyski W., Jenerat Zamoyski 1803-1868, 1853-1868 t. 6, Poznań 1930.

Zathey J., Katalog rękopisów średniowiecznych Biblioteki Kórnickiej, Wrocław i in. 1963. 